УДК 372.881.111.1,372.881.111.22

\title{
ЭКОЛОГИЧЕСКОЕ ОБРАЗОВАНИЕ И ВОСПИТАНИЕ НА УРОКАХ АНГЛИЙСКОГО И НЕМЕЦКОГО ЯЗЫКОВ
}

\author{
Милокумова Светлана Юрьевна \\ Постникова Татьяна Осиповна
} учителя

Научный руководитель: Колесникова Наталья Евгеньевна директор

МБОУ СОШ №18 г.Химки МО

\begin{abstract}
Аннотация: Сложность обозначенных в статье задач экологического образования и воспитания подрастающего поколения нацеливает на координацию деятельности педагогов, работающих в образовательных учреждениях. Сегодня требуются современные технологии, способные значительно повысить уровень экологического образования и воспитания общества. В силу этого требуется серьезная научно-методическая разработка подходов к планированию тем на уроках иностранного языка.
\end{abstract}

Ключевые слова: Экологическое воспитание, экологическое образование, экологическая культура, экологическое сознание, краеведческий материал, экологическая составляющая УМК.

\section{ENVIRONMENTAL EDUCATION AND UPBRINGING IN ENGLISH AND GERMAN LESSONS}

\section{Milokumova Svetlana Yuryevna \\ Postnikova Tatyana Osipovna \\ Kolesnikova Natalia Evgenievna}

В связи с реформами, которые проводятся в сфере народного образования и большими изменениями, затрагивающими все аспекты обучения и воспитания, экологическое образование и воспитание приобретает доминирующую позицию в педагогической деятельности.

В настоящее время перед школой стоит важная задача - воспитать поколение, которое будет способно во всех видах деятельности подчинить 
свои потребности идее о бережном использовании природных ресурсов, защите окружающей среды от разрушения и загрязнения.

Впервые А. Гумбольдт, а затем и Ж.-Ж. Руссо заговорили о воспитании у детей «чувства природы» как ощущения её облагораживающего влияния на человека. Я.А. Коменский с целью творческого сотрудничества детей с явлениями природы написал свою книгу «Видимый мир в картинках», обозначив важность непосредственного ознакомления ребенка с замечательным миром природы. Развитие эмоциональной сферы способствует знакомству с окружающими предметами и явлениями, усвоению образцов окружающего мира и лишь после этого умению действовать, используя приобретённые знания, навыки и умения.

Экологическое воспитание - это целенаправленный процесс. В зависимости от целевой группы и её возраста экологическое воспитание осуществляется различными методами, в разной среде деятельности. Экологическое воспитание отражает человека во всех сферах жизни: в его увлечениях, дома, на работе и в свободном времяпрепровождении. При этом оно учитывает личность как духовную, физическую и социальную целостность. Ценностное воспитание и формирование ответственности являются центральными элементами экологического воспитания на протяжении всей жизни. Ежедневно делая выбор, человек влияет на состояние окружающей среды. С точки зрения экологического воспитания важнейшим является осознание воздействия, исходящего от собственной деятельности, и нахождение более дружелюбного по отношению к окружающей среде образа действий. Имеет значение также и принятие на себя ответственности за собственные действия и их последствия.

Можно сделать вывод, что экологическое воспитание должно быть обязательной частью общеобразовательной подготовки учащихся.

Особое место в системе экологического образования отводится иностранному языку. Наряду с рассмотрением мировых экологических проблем в ходе изучения тем:

- «Страны изучаемого языка»,

- «Природа»,

- «Животный и растительный мир»,

- «Родной край»,

- «Традиции и обычаи»,

- «Здоровый образ жизни», 
- «Любимые животные»,

- «Защита окружающей среды» и т. д.

Авторы УМК «Английский в фокусе» Н.И. Быкова, Д.Дули, М.Д. Поспелова, В. Эванс, по которому работает наша школа, много раз возвращаются к теме защиты окружающей среды на разных ступенях обучения, предлагая обучающимся выполнить проекты по разным аспектам данной темы. На начальном этапе начинается знакомство с лексикой по соответсвующей тематике, т. е. начинает формироваться базовый словарь (название времен года, животных, явлений природы и др.).

Анализ УМК позволяет выявить определенную закономерность: лексический материал, обслуживающий экологическую проблематику, увеличивается из года в год, расширяется его сочетаемость.

Ведущими технологиями на наших уроках являются:

- исследовательские методы обучения;

- проектные методы обучения;

- технология дидактической игры;

- технология развития «критического мышления».

Так, в 5 классе один из Модулей учебника посвящен редким видам животных, где ребята узнают не только названия редких видов животных во всем мире, а также где они обитают, но и исследуют самостоятельно экологическую ситуацию в своей стране, в своем округе. При работе над данным модулем мы используем такие виды уроков как урок-путешествие, ролевую игру, устные опросы, а также полюбившиеся ребятами уроквикторину «Юный зоолог» и конкурсы. Ребята работают над своими проектами, и на данном этапе обучения выполняют такие работы как:

- Написание статьи на тему «Описание дикого животного»;

- Составление и обыгрывание диалога «Я в зоопарке»;

- Составление визитной карточки животного, обитающего в нашем округе.

Таким образом, уже с 5 класса на уроках английского языка учащиеся формируют и развивают экологическое мышление, экологическую культуру.

С 10 класса «Зеленые страницы» уже появляются в конце каждого модуля, и мы обсуждаем следующие экологические темы: «Циклы переработки», «Чистый воздух в доме», «Морские черепахи», «Тропические леса», «Загрязнения морей», «Органическое фермерство», «Бумага», 
«Альтернативная энергия». Урок начинается с обсуждения мудрых мыслей, заголовка статьи или с демонстрационного материала (картинка, музыка, диаграмма с данными, видеоролик), побуждающая ребят высказывать свое мнение, догадываться о теме урока, ставить перед собой задачи и формулировать вопросы, на которые они хотят узнать ответы. Затем, учащиеся получают и осмысливают новую информацию по теме. Организация работы на данном этапе может быть разнообразной. Это может быть рассказ, лекция, индивидуальное, парное или групповое чтение, или просмотр видеоматериала. Далее, мы обсуждаем прочитанное, и учащиеся делятся своими мнениями, таким образом, информация структурируется, превращаясь в новое знание. Возникшие вопросы или сомнения могут быть разрешены.

В рамках страноведческих тем на уроках немецкого языка рассматриваются экологические проблемы города и региона, в которых учащиеся живут, последствия экологических загрязнений и бедствий. Форма и методы могут быть самые различные, но используемый материал должен носить актуальный характер, отражать актуальные задачи экологического воспитания на примере близкого школьнику окружающего мира. Важную роль играют тексты, переводимые с русского языка на немецкий и с немецкого на русский, заимствованные из периодических изданий: „Deutschland“, „Јuma“, из сети Интернет, из справочников.

Особое внимание необходимо уделить процессу экологического воспитания на уроках немецкого языка в средней школе (7-9 классы). Согласно педагогам и психологам, именно на средней ступени мотивация к изучению иностранного языка имеет тенденцию снижаться. Причиной являются трудности, которые возникают в процессе овладения иностранным языком, отсутствие реальных возможностей применения языка в повседневной жизни и др. Следовательно, необходимо применение таких разнообразных форм и методов работы в урочное и внеурочное время, как ИКТ на уроках иностранного языка, метод проектов, игровой метод, подбор краеведческого материала и др.

Анализируя достигнутые результаты проделанной работы можно сделать следующие выводы:

1. Реализуется Федеральный государственный образовательный стандарт;

2. Решается задача экологического воспитания учащихся средствами учебного предмета «Английский язык» и «Немецкий язык»; 
3. Отработана методика выполнения учебно-исследовательских проектов экологической направленности на уроках английского и немецкого языков;

4. Реализуется создание учебно-исследовательских проектов экологической направленности, как формы творческой работы на уроках английского и немецкого языков.

\section{Список литературы}

1. М.М.Аверин, Ф.Джин и др., «Горизонты» Немецкий язык, учебник для общеобразовательных школ, Москва-Просвещение, 2019

2. Ю.Е. Ваулина, Д. Дули, и др. «Английский в фокусе» «Spotlight» учебник для общеобразовательных школ, Москва-Просвещение,2019. 